MaPan : Jurnal Matematika dan Pembelajaran

p-ISSN: 2354-6883 ; e-ISSN: 2581-172X

Volume 8, No 1, June 2020 (76-86)

DOI: https://doi.org/10.24252/mapan.2020v8n1a6

\title{
INVESTIGATING THE NUMBER SENSE ABILITY OF PRE-SERVICE MATHEMATICS TEACHERS
}

\author{
Nourma Pramestie Wulandari11), Vivi Rachmatul Hidayati2), Dwi Novitasari ${ }^{3)}$, \\ Tabita Wahyu Triutami'), Ulfa Lu'luilmaknun'5) \\ 1,3,4,5Program Studi Pendidikan Matematika, Universitas Mataram; 2Program Studi \\ Pendidikan Guru Sekolah Dasar, Universitas Mataram \\ 1,3,4,5J1. Majapahit No. 62, Kota Mataram; 2J1. Brawijaya No. 22, Kota Mataram \\ E-mail: nourmapw@unram.ac.id ${ }^{1}$, vivirachma@unram.ac.id²), \\ dwinovitasari@unram.ac.id ${ }^{3}$ ) tabita.triutami@unram.ac.id ${ }^{4)}$ ulfa_l@unram.ac.id ${ }^{5)}$
}

Received January 15, 2020; Revised March 03, 2020; Accepted May 28, 2020

\begin{abstract}
:
This research aims to identify the components of number sense of pre-service mathematics teachers. Pre-service mathematics teachers need a good number sense ability as a provision to transfer knowledge to students. This research uses a quantitative method. Subjects in this research are 14 third year pre-service mathematics teachers. The instrument used was in the form of 30 items of number sense questions that were developed based on number sense components, that is, understanding and skills about numbers, using number and operations on numbers, and using number and operation skills in calculations. The results showed that number sense ability of pre-service mathematics teachers' was still at a moderate level, which is $76.67 \%$. Preservice mathematics teachers also lack numbers' comprehension and skills elements.
\end{abstract}

Keywords: Number, Number Sense Ability, Pre-Service Mathematics Teacher

\section{IDENTIFIKASI KEMAMPUAN NUMBER SENSE MAHASISWA PENDIDIKAN MATEMATIKA}

\begin{abstract}
Abstrak:
Penelitian ini bertujuan untuk menyelidiki komponen number sense mahasiswa calon guru matematika. Calon guru matematika memerlukan kemampuan number sense sebagai bekal untuk mentransfer pengetahuan kepada siswa. Penelitian ini merupakan penelitian kuantitatif. Subjek penelitian adalah 14 calon guru matematika tahun ketiga. Instrumen yang digunakan berupa 30 item soal number sense yang dikembangkan berdasarkan komponen number sense, yaitu pemahaman dan keterampilan tentang bilangan dan penggunaan operasi bilangan, dan menerapkan keterampilan bilangan dan operasi dalam perhitungan. Hasil penelitian menunjukkan bahwa kemampuan number sense mahasiswa calon guru matematika masih berada pada level sedang yakni $76,67 \%$. Mahasiswa calon guru matematika masih lemah dalam komponen pemahaman dan keterampilan tentang bilangan.
\end{abstract}

Kata kunci: Bilangan, Kemampuan Number Sense, Calon Guru Matematika 
How to Cite: Wulandari, N. P., Hidayati, V. R., Novitasari, D., Triutami, T. W., \& Lu'luilmaknun, U. (2020). Investigating the Number Sense Ability of Pre-Service Mathematics Teachers. MaPan: Jurnal Matematika dan Pembelajaran, 8(1), 76-86. https://doi.org/10.24252/mapan.2020v8n1a6.

\section{INTRODUCTION}

$\mathrm{P}$ re-service teachers must have a good understanding and skills about numbers, especially for pre-service mathematics teachers. The knowledge and skills of pre-service mathematics teachers become necessary components in teaching and learning (Wasiu \& Abiola, 2019). It is a necessity to transfer knowledge to students efficiently. On the other hand, the teacher is expected to develop mathematical concepts supported by in-depth knowledge of the teacher's mathematical concept (Walidah, Kusaeri, \& Yudi, 2019). It also prevents students from hating mathematics learning. Furthermore, knowledge of numbers concept is used as the basis of the mathematics curriculum as well as in terms of understanding concepts such as measurement, algebra, geometry, and data analysis (NCTM, 2000). Mastery in processing numbers is known as number sense.

Number sense can be interpreted as a person's sensitivity to numbers and their calculations that are useful for solving problems that are not tied to traditional algorithms (Safitri, Mulyati, \& Chandra, 2017). Furthermore, number sense can also be interpreted as flexible thinking and intuition about numbers (Hadi, 2015). Someone who can have a good number sense will be able to develop abilities and strategies to make it easier to understand numbers and their interrelations. This understanding includes understanding the meaning of numbers, the use of numbers, and being able to interpret them, being able to do accurate calculations and having sharp analysis and reasoning on a problem related to numbers.

Sengul \& Gulbagci (2012) stated several characters of number sense, which includes the ability to understand and use the representation of different numbers and operations, the flexibility when performing mental calculations, the ability to recognize the results of calculations that are not possible, and fluency in estimating and determining the number. Number sense refers to a person's general understanding of numbers and operations, accompanied by the ability and tendency to use this understanding flexibly (McIntosh, Reys, \& Reys, 1992). Therefore, it can be said that a pre-service mathematics teacher who meets these characters is someone who has a good sense of number. 
McIntosh, Reys, \& Reys (1992) group number sense into three components that is knowledge of facility with numbers, knowledge of facility with operations, and applying knowledge of facility with numbers and operations to computational settings. Based on the grouping, Muir (2012) developed a framework to describe the indicators for each component of number sense. The component and indicators of number sense used in this study are indicated in table 1.

Table 1. Components and Indicators of Number Sense

\begin{tabular}{|c|c|}
\hline Components & Indicators \\
\hline \multirow{4}{*}{$\begin{array}{l}\text { A. Knowledge of facility with } \\
\text { numbers (understanding and } \\
\text { using numbers) }\end{array}$} & 1. Sense of orderliness of numbers \\
\hline & 2. Multiple representations for numbers \\
\hline & $\begin{array}{l}\text { 3. Sense of relative and absolute } \\
\text { magnitude of numbers }\end{array}$ \\
\hline & $\begin{array}{l}\text { 4. System of benchmarks that is using } \\
\text { students' expertise and experience in } \\
\text { assessing a different context }\end{array}$ \\
\hline \multirow[t]{3}{*}{$\begin{array}{l}\text { B. Knowledge of facility with } \\
\text { operations }\end{array}$} & $\begin{array}{l}\text { 1. Understanding the effect of } \\
\text { operations }\end{array}$ \\
\hline & $\begin{array}{l}\text { 2. Understanding mathematical } \\
\text { properties }\end{array}$ \\
\hline & $\begin{array}{l}\text { 3. Understanding the relationship } \\
\text { between operations }\end{array}$ \\
\hline \multirow{4}{*}{$\begin{array}{l}\text { C. Applying knowledge of } \\
\text { facility with number and } \\
\text { operations to computational } \\
\text { settings }\end{array}$} & $\begin{array}{l}\text { 1. Understanding the relationship } \\
\text { between problem context and the } \\
\text { necessary computation }\end{array}$ \\
\hline & $\begin{array}{l}\text { 2. Awareness that multiple strategies } \\
\text { exist }\end{array}$ \\
\hline & $\begin{array}{l}\text { 3. The inclination to utilize an efficient } \\
\text { representation and/or method }\end{array}$ \\
\hline & $\begin{array}{l}\text { 4. The inclination to review data and } \\
\text { result for sensibility }\end{array}$ \\
\hline
\end{tabular}

Everyone has a way of solving a problem based on their ability to interpret the problem according to their point of view (Maulyda \& Hidayati, 2019). Even so, if having a number sense ability, then students (especially preservice mathematics teachers) can solve the mathematical problems related to it better. Many studies have shown that various pre-service teacher backgrounds have low results in understanding numbers when given tests related to the 
component of number sense (Akkaya, 2015; Sengul, 2013; Yang, Reys, \& Reys, 2009; Yaman, 2015; Aktas \& Ozdemir, 2017). Besides, the results of research conducted by Sengul (2013) show that pre-service elementary teachers' number sense is still deficient and tends to use a "rule-based method" rather than "number sense" on each component tested (Koleza \& Koleli, 2014). Lemonidis \& Kaimakami (2013) in their research on the knowledge of elementary school teacher's number sense in computational estimation gives the results that elementary school teachers show low performance on number sense, limitations in the ability of mental operations, especially the case of double-digit multiplication and the case of the division with two digits divisor. Tsao \& Lin (2012) found that teachers without a background in mathematics or physics have less knowledge about number sense. The other study state that one of the mistakes in solving mathematical problems is when doing calculations and numeric operations (Hadiyanto \& Wulandari, 2019).

Based on the above studies, not much research has been done on preservice mathematics teachers for higher levels, especially in Indonesia. Therefore, this research aims to identify the components of number sense that are poorly mastered by pre-service mathematics teachers. Based on the results of this study, it is hoped that in the future, a solution can be found to train the number sense abilities possessed by pre-service mathematics teachers.

\section{RESEARCH METHOD}

The method used in this research is quantitative, with respondents are 14 third year pre-service mathematics teachers. Data in this research are scores from the work of 14 subjects who completed 30 item number sense questions. The scoring method is to give a score, 1 if the subject's answer is correct and 0 if the subject's answer is wrong. Data were analyzed using Microsoft Excel. Then they will be analyzed by descriptive method.

The number sense instrument is 30 questions that are solved by the preservice mathematics teachers for 30 minutes. The question instruments are constructed so that the instruments can be used to investigate the components of number sense that are poorly mastered by pre-service mathematics teachers. Each question item is grouped into three aspects based on each component represented and with instructions for answering the question items with a mental calculation. The question items were modified from Muir (2012).

Example test questions for the components of understanding and skills about numbers, "how many decimal numbers differ between 1.52 and 1.53?". 
Respondents were asked to compare the value of the calculation to determine many different numbers at a certain interval. The aspect represented is that the respondent is expected to have a sensitivity to the magnitude value of a number.

Example test questions for the components of understanding and skills using number operations, "if $93 \times 143=13299$, then $93 \times 137=\ldots "$. This question item asks respondents to be able to understand the relationship between number operations by applying skills to the relationship between multiplication operations and division operations.

Example test questions for the components of using number and operation skills in calculation "Nine students of SMP Bahagia want to take a vacation by car. If a car can accommodate a maximum of 4 passengers, how many cars are needed for the nine children?". The ability of respondents to understand the relationship between contextual problems and actual calculations are needed in solving this item problem, especially regarding rational thinking of the results obtained.

\section{RESULTS AND DISCUSSION}

Based on the results of data collection, the following is the percentage of correct answers based on items and number sense components and showed in table 2 .

Table 2. Percentage of Correct Answers for Component A1.

\begin{tabular}{ccccccccc}
\hline \multicolumn{8}{c}{ A1. Understanding and Skills About Number } \\
\hline & Q6 & Q14 & Q15 & Q16 & Q17 & Q21 & Q22 \\
Correct Answers & 8 & 10 & 7 & 12 & 6 & 14 & 13 \\
Percentage (\%) & 57.14 & 71.43 & 50 & 85.71 & 42.86 & 100 & 92.86 \\
& & & Question Items & & & \\
Correct Answers & 9 & 11 & 10 & 4 & 8 & 12 & \\
Percentage (\%) & 64.29 & 78.57 & 71.43 & 28.57 & 57.14 & 85.71 \\
\hline
\end{tabular}

These results indicate the diversity of the percentage of correct answers to subjects on one component. Some questions have a low percentage, which is below $50 \%$, but some have a relatively large percentage of success, which is above $90 \%$. 
Table 3. Percentage of Correct Answers for Component A2

\begin{tabular}{lccccccc}
\hline \multicolumn{10}{c}{ A2. Understanding and Skills Using Number } \\
\hline & Q1 & Q2 & Q3 & Q4 & Q5 & Q8 & Q29 \\
Correct Answers & 13 & 13 & 12 & 13 & 13 & 14 & 11 \\
Percentage (\%) & 92.86 & 92.86 & 85.71 & 92.86 & 92.86 & 100 & 78.57 \\
\hline
\end{tabular}

Based on the data in table 3 , most subjects can correctly answer questions on the understanding and skills using number components. It is because the entire percentage of success is above $50 \%$. In general, for the first number sense component, namely knowledge of facility with the number (understanding and using numbers), only three questions have the most prominent error frequency. It can be seen in questions number 15,17 , and 26 . So, it can be interpreted that the pre-service mathematics teacher is capable of this number sense component. They did not experience significant difficulties in solving the questions for the first component. In other words, pre-service mathematics teachers can be flexible in counting numbers (Mohamed \& Johnny, 2010; Yang, 2005; Yang \& Li, 2008). According to Altay \& Umay (2013), flexibility in counting is practical thinking in using mathematical operations, making various numbers of representations, and can find various ways to solve problems more efficiently.

Table 4. Percentage of Correct Answers for Component B

\section{B. Understanding and Skills Using Operation on Numbers}

\begin{tabular}{cccc}
\hline & \multicolumn{3}{c}{ Question Items } \\
Q18 & Q19 & Q20 \\
Correct Answers & 10 & 13 & 9 \\
Percentage (\%) & 71.43 & 92.86 & 64.29 \\
\hline
\end{tabular}

There are three questions in the component of understanding and skill using operations on numbers. The question with the lowest percentage of correct answers is Q20, which is 64.29\%. Q20 contains the questions: "If $93 \times 184=17112$, then $17112 \div 930=\ldots "$. In this case, pre-service mathematics teachers do not complete Q20 based on number sense methods. Q20 is solved using the usual division method, which is $17112 \div 930=\cdots$, and does not utilize the multiplication value given earlier in the question. 
Table 5. Percentage of Correct Answers for Component C

\begin{tabular}{cccccccc}
\hline \multicolumn{8}{c}{ C. Understanding and Skills Using Number } \\
\hline \multicolumn{10}{c}{ Question Items } \\
Correct Answers & 8 & Q9 & Q10 & Q11 & Q12 & Q13 & Q28 \\
Percentage (\%) & 57.14 & 92.86 & 64.29 & 92.86 & 85.71 & 78.57 & 78.57 \\
\hline
\end{tabular}

Based on table 5, the percentage of correct answers for each question varies considerably, the smallest percentage of correct answers owned by Q7. There were 8 out of 14 subjects who could answer Q7 correctly so that the percentage owned was $57.14 \%$. Q7 contains the questions: "If a number is entered in the following box, it can make the following statement to be true. $184 \times 148 \times \square=\square \times 148$. What is the number? In this case, students make many mistakes in placing the product of multiplication in decimal numbers. More answers given are 0.1 . If given that value, the left side result is 18,4 , and the other side result is 1.84 , so that it not equal. From these results, it appears that some students do not have a good sensitivity in understanding and skills in using numbers.

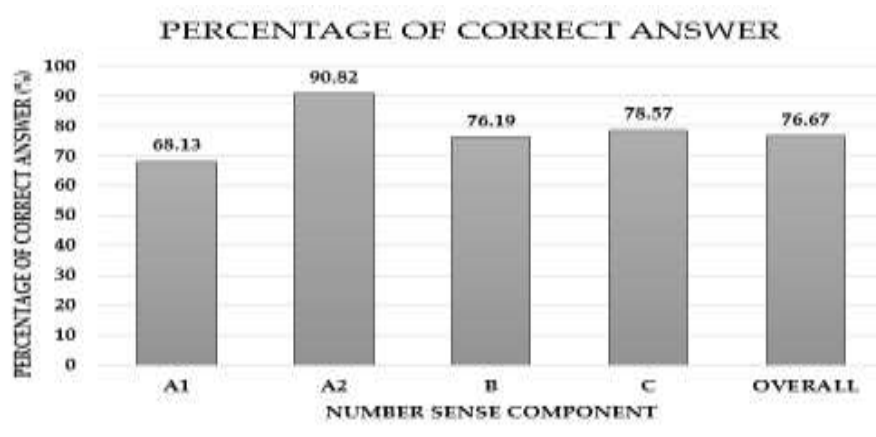

Figure 1. Diagram of Percentage of Correct Answer

Based on figure 1, the lowest average percentage of correct answers is in component A1, which is $68.13 \%$. It shows that understanding and skills ability of subjects about numbers is still low. The largest percentage of correct answers is in the A2 component, which is $90.82 \%$. It means that the understanding and ability to use numbers by subjects are classified as good. The average overall component, the percentage of correct answers is $76.67 \%$.

After analyzing the percentage of correct answers based on the problems in each component, then the data analysis capabilities of the number sense of each subject will be presented in each component. Research subjects who 
correctly answered a maximum of $67 \%$ of the questions were categorized as low, subjects who responded $67 \%$ to $87 \%$ of the questions correctly were categorized as average and will be categorized as good if the subjects answered $87 \%$ to $100 \%$ of the questions correctly. This categorization is based on the modification of Safitri, Mulyati, \& Chandra (2017).

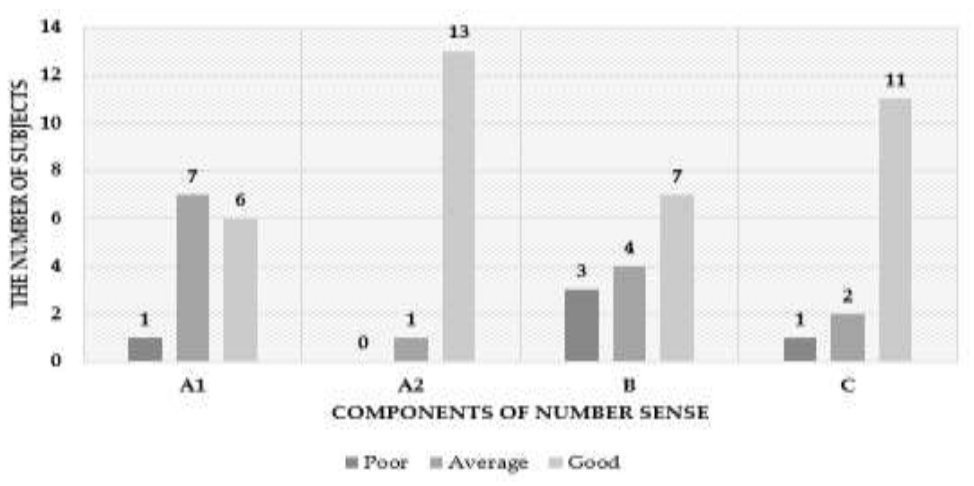

Figure 2. Diagram of Subjects' Number Sense Performance Based on Components

Based on figure 2, it appears that for the understanding and skills about numbers component, most subjects fall into the average category. Almost all subjects showed good performance when solving problems that were included in the components of understanding and skill using numbers. As many as half of the subjects showed good performance when solving problems for the component of understanding and skill using operations on numbers. Good performance is also shown by the subject when solving problems for the components of using numbers and operation skills in the calculation.

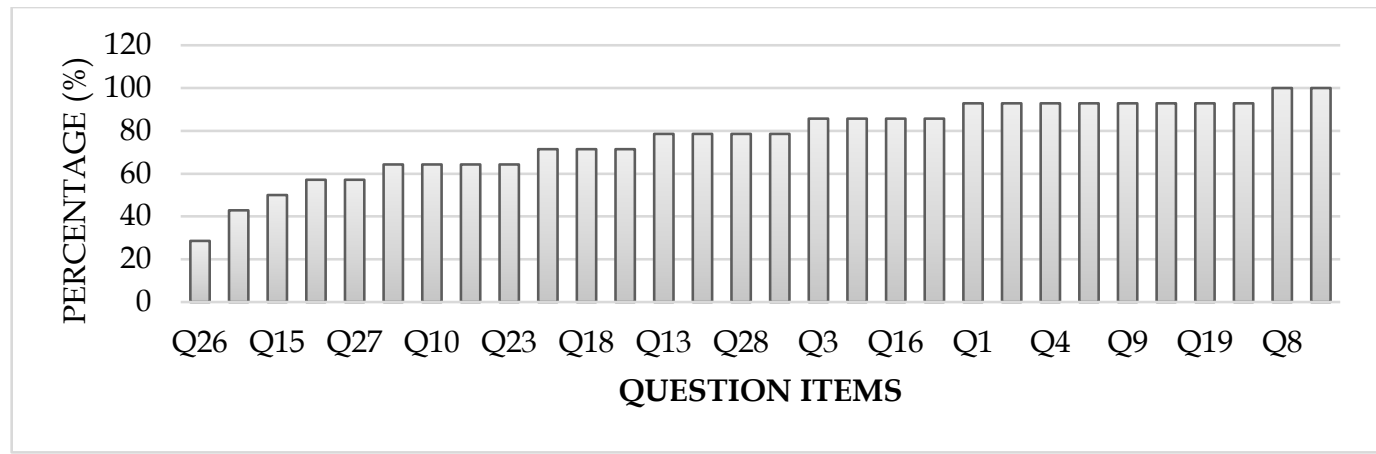

Figure 3. Percentage of Correct Answers for All Question Items

Based on figure 3, two questions have a percentage of correct answers of less than 50\%. The two questions are Q26 and Q17. Q26 has the lowest percentage of 
correct answers. Q26 is included in the number component, the sense of understanding and skills about numbers. The following is the question of Q26.

"Circle all true statements about numbers 3/7.

a. Greater than $1 / 2$

b. Equals to 2.5

c. Equivalent with 0.4

d. Greater than 1/3"

The correct answer is point $d$. Most subjects answered points c. Subject understanding and skills regarding numbers are still lacking. The following is the question of Q17.

"There are two even numbers with two digits. The two numbers are different. The difference between the two numbers is 4 , and the sum of the constituent digits of the two numbers is 8 . What are the numbers? and

Q17 is included in the number sense component of understanding and skills about numbers. Some subjects have answered correctly; those are 20 and 24 . Some students still experience errors in writing numbers 2 and 6. It shows that the subject still lacks the mastery of using numbers because the requested problem is two digits.

\section{CONCLUSION}

The percentage of pre-service mathematics teachers' ability to solve number sense questions is $76.67 \%$. This percentage shows that the number sense ability of pre-service mathematics teachers' was still at a moderate level. Preservice mathematics teachers still lack in understanding and skills about numbers component. Some questions on this component have a relatively low percentage of correct answers. Based on the results of this study, it is hoped that in the future, a solution can be found to train the number sense abilities of preservice mathematics teachers, especially in understanding and skills about numbers.

\section{REFERENCES}

Akkaya, R. (2015). An investigation into the number sense performance of secondary school students in Turkey. Journal of Education and Training Studies, 4(2), 113-123. https:/ / doi.org/10.11114/jets.v4i2.1145.

Altay, K. M., \& Umay, A. (2013). The development of number sense scale towards middle grade students. Egitim Ve Bilim-Education and Science, 38(167), 241-255. Retrieved from https://avesis.hacettepe.edu. tr/yayin/99ef796a-876f-44d5-b1b4-baa1b9bb5690/the-development-of- 
number-sense-scale-towards-middle-grade-students.

Aktas, M. C., \& Ozdemir, E. T. (2017). An examination of number sense performances of preservice elementary school mathematics teachers. European Journal of Education Studies, 3(12), 133-144. https://doi.org/10. 5281/zenodo.1117088.

Hadi, S. (2015). Number sense : Berpikir fleksibel dan intiusi tentang bilangan. Math Didactic: Jurnal Pendidikan Matematika, 1(1), 1-7. Retrieved from http: // eprints.ulm.ac.id/2128/.

Hadiyanto, F. R., \& Wulandari, N. P. (2019). Identifikasi Kesalahan siswa kelas vii dalam menyelesaikan soal cerita geometri dengan newman's procedure. Mandalika Mathematics and Education Journal, 1(2), 81-86. https://doi.org/10.29303/mandalika.v1i2.1512.

Koleza, E., \& Koleli, M. (2014). Investigating prospective elementary teachers' number sense through mental computation strategies. MENON: Journal Of Educational Research., 1st Thematic Issue Florina, 126-143. Retrieved from http://www.edu.uowm.gr/site/book/export/html/487.

Lemonidis, C., \& Kaimakami, A. (2013). Prospective elementary teachers' knowledge in computational estimation. MENON: Journal Of Educational Research., Issue 2b, 86-98. Retrieved from https://edu.uowm.gr/ site/sites/default/files/charalambos_lemonidis_anastasia_kaimakami_ prospective_elementa.pdf.

Maulyda, M. A., \& Hidayati, V. R. (2019). Representasi matematis visual anak ditinjau dari bakat musik. EDU-MAT: Jurnal Pendidikan Matematika, 7(2), 149-158. https:// doi.org/10.20527/edumat.v7i2.6855.

McIntosh, A., Reys, B. J., \& Reys, R. E. (1992). A proposed framework for examining basic number sense. For the Learning of Mathematics, 12(3), 2-8. Retrieved from https://flm-journal.org/Articles/94F594EF72C03412F1 760031075F2.pdf.

Mohamed, M., \& Johnny, J. (2010). Investigating number sense among students. 8(5), 317-324. https:/ / doi.org/10.1016/j.sbspro.2010.12.044.

Muir, T. (2012). What is a reasonable answer? Ways for students to investigate and develop their number sense. Australian Primary Mathematics Classroom, 17(1), 21-28. Retrieved from https://files.eric.ed.gov/ fulltext/EJ978131.pdf.

NCTM. (2000). Principles and standards for school mathematics. In The National Council of Teachers of Mathematics, Inc. The National Council of Teachers of Mathematics, Inc. Retrieved from https://www.cambridge. 
Nourma Pramestie Wulandari1), Vivi Rachmatul Hidayati2), Dwi Novitasari3), Tabita Wahyu Triutami4), Ulfa

Lu'luilmaknun ${ }^{5}$

org/core/product /identifier/S0007125000082039/type/journal_article. Safitri, A. S., Mulyati, S., \& Chandra, T. D. (2017). Kemampuan number sense siswa sekolah menengah pertama kelas VII pada materi bilangan. Prosiding SI MaNIs (Seminar Nasional Integrasi Matematika dan Nilai Islami), 1(1), 270-277. Retrieved from http://conferences.uin-malang.ac.id/ index.php/SIMANIS/article/view/85.

Sengul, S. (2013). Identification of number sense strategies used by pre-service elementary teachers. Educational Sciences: Theory \& Practice, 13(3), 19651974. https://doi.org/10.12738/estp.2013.3.1365.

Sengul, S., \& Gulbagc1, H. (2012). Evaluation of number sense on the subject of decimal numbers of the secondary stage students in Turkey. International Online Journal of Educational Sciences, 4(2), 296-310. https://doi.org/ 10.1016/j.sbspro.2012.05.472.

Tsao, Y.-L., \& Lin, Y.-C. (2012). Elementary school teachers' understanding towards the related knowledge of number sense. US-China Education Review B, 1, 17-30. Retrieved from https://eric.ed.gov/?id=ED531655.

Walidah, N. Z., Kusaeri, \& Yudi, U. (2019). Mengoptimalkan dukungan guru dalam melibatkan siswa menggunakan argumentasi kolektif pada pembelajaran matematika. MaPan: Jurnal Matematika dan Pembelajaran, 7(2), 261-280. https://doi.org/10.24252/mapan.2019v7n 2a7.

Wasiu, O. I., \& Abiola, O. A. (2019). Enhancing the conceptual, procedural, and flexible procedural knowledge of pre-service mathematics teachers in algebra. 4(2), 66-78. https://doi.org/10.23917/jramathedu.v4i2.8363.

Yaman, H. (2015). The mathematics education i and ii courses' effect on teacher candidates' development of number sense. Educational Sciences: Theory $\mathcal{E}$ Practice, 15(4), 1119-1135. https:// doi.org/10.12738/estp.2015.4. 2322.

Yang, D. C., Reys, R. E., \& Reys, B. J. (2009). Number sense strategies used by pre-service teachers in Taiwan. International Journal of Science and Mathematics Education, 7(2), 383-403. https://doi.org/10.1007/s10763007-9124-5.

Yang, D. (2005). Number sense strategies used by 6th-grade students in Taiwan. Educational Studies, 31(3), 317-333. https://doi.org/10.1080/ 03055690500236845.

Yang, D., \& Li, M. F. (2008). An investigation of 3rd-grade Taiwanese students' performance in number sense. Educational Studies, 34(5), 443-455. https://doi.org/10.1080/03055690802288494. 